\title{
Study of Neuropeptide Substance $P$ as A Marker of Pain in Newborn Infant
}

\author{
Safaa ELMeneza ${ }^{1 *}$ (D) Iman Elbagoury ${ }^{2}$ (D) Enas Tawfik $^{1}$ (D) Amel Tolba ${ }^{1}$ (D) \\ ${ }^{1}$ Department of Pediatric, Faculty of Medicine for Girls, AL-Azhar University, Cairo, Egypt; ${ }^{2}$ Department of Clinical Pathology, \\ Faculty of Medicine for Girls, AL-Azhar University, Cairo, Egypt
}

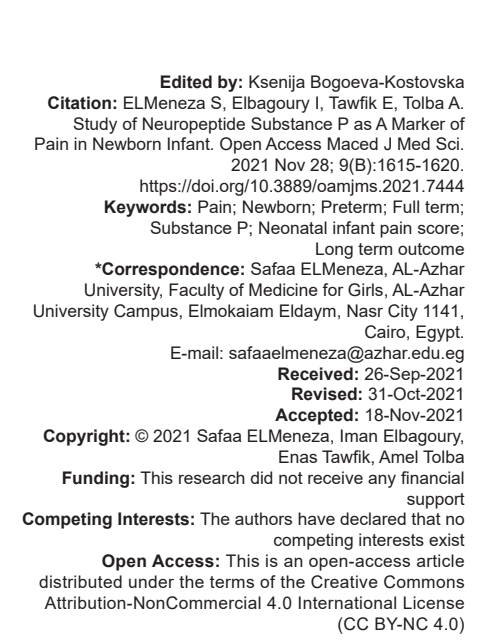

\section{Introduction}

Majority of newborn infants in neonatal intensive care unit (NICU) are subjected to some grade of pain and stress. They expose to repetitive handling, painful procedures, and separation from mothers during a period of rapid brain growth [1]. Even procedures as bathing, weighing, noxious sounds, lights, and diaper changes are perceived as stress to the infant [2].

Newborn infants respond to harmful stimuli by a succession of multiple biochemical, physiologic, and behavioral changes. The untreated pain has been reported to cause negative effects on both short-term and long-term consequences in the infant's brain development and quality of life.

Prolonged and repeated untreated pain in the newborn period, may produce a relatively permanent shift in basal autonomic arousal, which may have long-term sequelae. In the long run, the most significant clinical effects of early pain exposure may be on neurodevelopment, contributing to later attention, learning, and behavior problems in these vulnerable children. There is functional change in cortical pain sensitivity processing in the brain in older ex-preterm children that may allow the development of a more rational approach to pain management in NICU [3]. One of the seven neuroprotective core measures for family-centered developmental care of the premature neonate is minimizing stress and pain [4].

The neonatal infant pain scale (NIPS) is a behavioral scale and can be utilized with both full-term and pre-term infants. It is composed of six indicators that allow for the estimation of pain grade in newborn infants [5].

Substance $P(S P)$ is a highly conserved member of the tachykinin neuropeptide family. SP mRNAs are present in striatal neuronal populations from week 12 of fetal life. SP is involved in a multitude of neuronal signaling pathways, mediating sensations and emotional responses and transmission and modulation of pain signals by activating the neurokinin-1 (NK-1) receptor [6]. It transmits nociceptive signals via primary afferent fibers to spinal and brainstem second-order neurons. 
Pain control is important for many reasons but overuse of morphine or benzodiazepines may have undesirable long-term effects [7]. Animal evidence suggests that the neonatal brain is affected differently when exposed to morphine administered in the absence of pain than in the presence of pain. Safety and efficacy are the major concerns in the selection of an appropriate pain-relieving treatment in infants [8], [9].

Although the effect of pain and stress exposure on neurodevelopment in preterm infants is well-documented, the potential role for SP as neurochemical markers of pain in neonates has not been fully investigated. SP in plasma of adult has been associated with pain.

\section{Research questions}

Can SP be used as potential neurochemical marker for diagnosis and management of pain in sick full term and preterm infants?

\section{Objectives}

Evaluate the potential role for neuropeptides SP as neurochemical pain marker in newborn infants in order to manage pain adequately, decrease unnecessary use of sedatives and analgesics, protect developing brain and promote better long-term outcome.

\section{Materials and Methods}

\section{Subjects}

The present study included 60 neonates, who were admitted to NICU. They were allocated to two groups according to gestational (GA) age; full-term and preterm groups. The full term group was subdivided into control group (10 normal full term) and 20 sick full-term neonates. The preterm group included control group (10) and sick preterm term infants (20) cases.

The sick preterm aged from 32 to 36 weeks of gestations while full-term GA ranged from 37 to 42 weeks.

\section{Study design}

This was case-control study to evaluate the potential role of SP as pain markers. All neonates were subjected to full complete history taking and thorough clinical examination, estimation of NIPS before and after procedures of checkup, routine care, or painful procedures. The NIPS addresses 5 behavioral parameters (facial expression, crying, arm movement, leg movement, and state arousal) and 1 physiological parameter (breathing pattern). Each behavioral indicator is scored with 0 or 1 except "cry," which has three possible descriptors, therefore, being scored with a 0 , 1, or 2 [10]. Infants were observed for $1 \mathrm{~min}$ in order to fully assess each indicator. Total pain scores range from 0 to 7 . We considered mild or no pain if 0-2, mild-to-moderate if 3-4, moderate-to-severe 4-5 severe if $>5$. It was done at the $1^{\text {st }}$ day, before and after the invasive procedures as well as on the $5^{\text {th }}$ day.

Serum level of SP was estimated in the $1^{\text {st }}$ and $5^{\text {th }}$ days using Assay Designs' Correlate EIATM SP kit. The samples were taken in relation to the routine investigations in the morning for the newborn infants whether control or sick groups.

Invasive procedure includes skin-breaking procedures, mechanical ventilation, arterial puncture, bronchoscopy, endoscopy, heel lancing, lumbar puncture, suprapubic bladder tap, venipuncture, bladder catheterization, central line insertion/removal, chest tube insertion/removal, intramuscular injection laser therapy for retinopathy, peripheral venous catheterization.

Noninvasive procedures include removal of adhesive tape, wound treatment, apply eye shield during phototherapy, apply monitor electrode, change diaper, eye examination, chest physiotherapy, gavage tube insertion, postural drainage, suture removal, and retinopathy of prematurity examination.

Informed consent was taken from the parents of the involved neonates and the study was approved by the ethical committee of the Faculty of Medicine for Girls, AL-Azhar University, number 202103751. The registration number is IRB00012239.

\section{Statistical analysis of data}

The collected data were validated and verified, organized, tabulated, and analyzed using statistical package for social software statistical computer package version 12. For qualitative data number and percent were calculated and for comparison between the variables Chi-square $\left(\chi^{2}\right)$ test was used. For quantitative data mean and standard deviations were calculated and independent samples students (t) test was used to compare between two means. For comparison between more than two means, one-way analysis of variance was used. Paired, samples (t) test was used to compare two means at different times $\left(1^{\text {st }}\right.$ and $5^{\text {th }}$ day). Pearson's correlation coefficient was used for correlation between NIPS and SP. $p$ value considered to be significant when $<0.05$.

\section{Results}

The results are shown from Tables 1-6. 
Table 1: Demographic data of the studied groups

\begin{tabular}{|c|c|c|c|c|c|c|}
\hline Mean \pm SD & Control Preterm & Sick preterm & Control Full term & Sick full term & $\mathrm{F}$ & $\mathrm{p}$ \\
\hline Gestational age (wks.) & $35 \pm 1.34$ & $35.26 \pm 3.47$ & $38.40 \pm 1.34$ & $38.60 \pm 0.94$ & 9.02 & 0.001 \\
\hline Gender Male & $6(60 \%)$ & $13(65 \%)$ & $7(70 \%)$ & $7(35 \%)$ & Chi-square 5.05 & 0.168 \\
\hline Female & $4(40 \%)$ & $7(35 \%)$ & $3(30 \%)$ & $13(65 \%)$ & & \\
\hline Birth weight (g) & $2890 \pm 246.53$ & $2657 \pm 262.78$ & $3354.00 \pm 146.53$ & $3335 \pm 155.74$ & 27 & 0.001 \\
\hline Length $(\mathrm{cm})$ & $47.20 \pm 2.1$ & $46.90 \pm 1.16$ & $49.20 \pm 1.03$ & $48.40 \pm 1.27$ & 34.12 & 0.001 \\
\hline Apgar score $1 \mathrm{~min}$ & $8.20 \pm 1.4$ & $7.20 \pm 1.50$ & $8.80 \pm 1.03$ & $7.75 \pm 1.77$ & 6.56 & 0.036 \\
\hline Apgar score $\min 5$ & $9.5 \pm 0.67$ & $7.30 \pm 1.89$ & $9.70 \pm 0.67$ & $8.20 \pm 1.73$ & 6.99 & 0.002 \\
\hline
\end{tabular}

The study was performed on 60 newborn infants with gestation age ranged from 32 to 42 weeks. There was significant difference in GA, birth weight (BW), and length in the preterm groups than the full-term group and non-significant difference as regard to gender.

Table 2: Pain score response to invasive and non-invasive procedures among the studied groups

\begin{tabular}{|c|c|c|c|c|c|c|c|c|}
\hline \multirow[t]{2}{*}{ Pain score } & \multicolumn{2}{|c|}{$\begin{array}{l}\text { Preterm } \\
\text { Invasive }\end{array}$} & \multicolumn{2}{|c|}{$\begin{array}{l}\text { Preterm Non } \\
\text { invasive }\end{array}$} & \multicolumn{2}{|c|}{$\begin{array}{l}\text { Full term } \\
\text { invasive }\end{array}$} & \multicolumn{2}{|c|}{$\begin{array}{l}\text { Full term } \\
\text { non-invasive }\end{array}$} \\
\hline & No & $\%$ & No & $\%$ & $\mathrm{n}$ & $\%$ & $\mathrm{n}$ & $\%$ \\
\hline Mild or no pain & 0 & $0.0 \%$ & 5 & $50.0 \%$ & 0 & $0.0 \%$ & 4 & $40.0 \%$ \\
\hline Moderate & 0 & $0.0 \%$ & 5 & $50.0 \%$ & 1 & $10.0 \%$ & 6 & $60.0 \%$ \\
\hline Moderate to severe & 3 & $30.0 \%$ & 0 & $0.0 \%$ & 5 & $50.0 \%$ & 0 & $0.0 \%$ \\
\hline Severe pain & 7 & $70.0 \%$ & 0 & $0.0 \%$ & 4 & $40.0 \%$ & 0 & $0.0 \%$ \\
\hline Statistics & \multicolumn{4}{|c|}{$\mathrm{Chi}^{2}=16.66 / \mathrm{p}<0.001$} & \multicolumn{4}{|c|}{$\mathrm{Chi}^{2}=9.09 / \mathrm{p}=0.011$} \\
\hline
\end{tabular}

Table 3: Substance $P$ at $1^{\text {st }}$ and $5^{\text {th }}$ day in the studied groups

\begin{tabular}{lllll}
\hline Substance P levels $(\mathrm{pg} / \mathrm{ml})$ & Mean & S. D & $\mathrm{t}$ & $\mathrm{p}$ \\
\hline $\begin{array}{l}\text { Control preterm } \\
1^{\text {st }} \text { day }\end{array}$ & 1.45 & 0.6 & 6.096 & 0.001 \\
$\quad 5^{\text {th }}$ day & 3.6 & 0.99 & & \\
$\begin{array}{l}\text { Control full term } \\
1^{\text {st }} \text { day }\end{array}$ & 1.30 & 0.82 & 2.14 & 0.046 \\
$5^{\text {th }}$ day & 1.95 & 0.50 & & \\
Sick Preterm & & & & \\
$\quad 1^{\text {st }}$ day & 2.58 & 0.88 & -2.435 & 0.025 \\
$\quad 5^{\text {th }}$ day & 3.6 & 0.99 & & \\
Sick Full term & & & & \\
$\quad 1^{\text {st }}$ day & 2.01 & 1.75 & 1.927 & 0.070 \\
$5^{\text {th }}$ day & 3.17 & 0.75 & & \\
\hline
\end{tabular}

APGAR score, was significantly increased in control groups than sick preterm and sick full-term groups at the $1^{\text {st }}$ and $5^{\text {th }}$ min.

Further study of significance between the studied variables by post hoc test, showed that GA age was significantly decreased in control preterm and sick preterm than control full term, $p=0.029$, and $<0.001$. Furthermore, there was a significant decrease in the GA of sick preterm than sick full term, $p=0<0.001$. There were no significant differences between control and sick preterm groups, $p=0.3427$ as well as control and sick full-term group as $p=0.415222$.

Table 4: Comparison of substance $P$ values at the $1^{\text {st }}$ and $5^{\text {th }}$ day after invasive procedures among the studied groups

\begin{tabular}{lllll}
\hline Substance p levels $(\mathrm{pg} / \mathrm{ml})$ & Mean & S. D & $\mathrm{t}$ & $\mathrm{p}$ \\
\hline $\begin{array}{l}\text { Preterm } 1^{\text {st }} \text { day } \\
\quad \text { Control }\end{array}$ & 1.45 & 0.6 & 3.355 & 0.003 \\
$\quad$ Sick Preterm & 2.58 & 0.88 & & \\
Preterm $5^{\text {th }}$ day & & & & \\
$\quad$ Control & 2.84 & 0.4 & -2.251 & 0.037 \\
$\quad$ Sick Preterm & 3.6 & 0.99 & & \\
Full term $1^{\text {st }}$ day & 1.30 & 0.82 & 1.162 & 0.260 \\
$\quad$ Control & 2.01 & 1.75 & & \\
$\quad$ Sick Full term & 1.95 & 0.50 & 4.280 & 0.005 \\
Full term 5 $5^{\text {th }}$ day & 3.17 & 0.75 & & \\
$\quad$ Control & & & & \\
$\quad$ Sick Full term & 2.58 & 0.88 & -0.920 & 0.369 \\
$1^{\text {st }}$ day & 2.01 & 1.75 & & \\
$\quad$ Sick Preterm & & & & \\
$\quad$ Sick Full term & 3.5 & 0.99 & -0.840 & 0.412 \\
$5^{\text {th }}$ day & 3.17 & 0.75 & & \\
$\quad$ Sick Preterm & & &
\end{tabular}

Concerning BW, post hoc test, showed that BW was not quite significantly different between control preterm and sick preterm as $p=0.0552$, but there was significant decrease of BW in sick preterm than sick full term infants, $p<0.0001$. Post hoc test showed also, significant decrease in BW of sick preterm than control full term and in control preterm infants than control fullterm infants, $p<0.001$.

Regarding the length post hoc test, showed that length was significantly increased in the control full- term infants than sick preterm infants as $p=0.0012$. Furthermore, there was a significant increase in the control full term than sick preterm infants as $p=0.0001$, and in sick full term than sick preterm infants as $p=0.0113$. No significant differences in length between the control and sick full-term infants as $p=0.1392$, also no significant difference between the sick and control preterm infants as $p=0.6937$.

Table 5: Comparison between cases need invasive procedures and non-invasive procedure

\begin{tabular}{lllllll}
\hline Substance P levels $(\mathrm{pg} / \mathrm{ml})$ & Mean & S. D & Minimum & Maximum & $\mathrm{t}$ & $\mathrm{p}$ \\
\hline Preterm At $1^{\text {st }}$ day & & & & & & \\
$\quad$ Invasive & 3.58 & 2.15 & 0.60 & 10.50 & -3.327 & 0.003 \\
$\quad$ Non invasive & 1.25 & 0.53 & 0.50 & 2.10 & & \\
$\begin{array}{l}\text { Preterm At the 5 } 5^{\text {th }} \text { day } \\
\quad \text { Invasive }\end{array}$ & 3.68 & 2.37 & 0.30 & 11.60 & 2.979 & 0.008 \\
$\quad$ Non invasive & 1.37 & 0.53 & 0.50 & 2.30 & & \\
$\quad \begin{array}{l}\text { Full term At 1 } 1^{\text {st }} \text { day } \\
\quad \text { Invasive }\end{array}$ & 2.83 & 2.17 & 0.90 & 8.00 & 2.322 & 0.032 \\
$\quad$ Non invasive & 1.19 & 0.53 & 0.50 & 2.10 & & \\
$\quad \begin{array}{l}\text { Full term At the 5 } 5^{\text {th }} \text { day } \\
\quad \text { Invasive }\end{array}$ & 3.06 & 2.11 & 1.30 & 8.10 & -2.567 & 0.019 \\
$\quad$ Non invasive & 1.29 & 0.55 & 0.60 & 2.20 & & \\
\hline T: T student test. & & & & & &
\end{tabular}

Further study of differences in Apgar score at $1 \mathrm{~min}$ by post hoc test, showed that there were no differences between all groups, except between sick preterm infant and control full term hence $p=0.0123$.

Considering Apgar score at $5 \mathrm{~min}$, post hoc test showed that, there was significant increase in the value of Apgar score at $5 \mathrm{~min}$ in the control preterm than sick preterm as $p=0.0037$, also there was increase in the control full-term infants than sick full infants because $p=0.0198$ and increase in the control full term than sick preterm infants as $p=0.0019$.

There was significant increase in grade of severe pain among sick preterm infants due to invasive procedures, while response to noninvasive procedures was mild or moderate response $p<0.001$. The sick full-term neonates response to invasive procedure was moderate to severe in $50 \%$ of cases and severe in $40 \%$ of cases, while the response to noninvasive procedures was mild or no in $40 \%$ of cases and moderate to noninvasive in $60 \%, p=0.011$ (Table 2). 
Table 6: Correlation between pain score NIPS at the $1^{\text {st }}$ and $5^{\text {th }}$ day and substance $P$ levels

\begin{tabular}{lllll}
\hline Pain Scale & \multicolumn{2}{l}{ Substance $\mathrm{p}$} & & \\
& \multicolumn{2}{l}{ Basic At 1 st $^{\text {di }}$} & $\begin{array}{l}\text { After invasive procurer } \\
\text { in preterm neonate }\end{array}$ & $\begin{array}{l}\text { After invasive procurer } \\
\text { in Full term neonate }\end{array}$ \\
\cline { 2 - 5 } & $\mathrm{r}$ & 0.36 & 0.43 & 0.39 \\
Pain Scale & $\mathrm{p}$ & 0.009 & 0.002 & 0.005 \\
\cline { 2 - 5 } & At 5 $5^{\text {th }}$ day & After invasive procurer & $\begin{array}{l}\text { After invasive procurer } \\
\text { in preterm neonate }\end{array}$ \\
\cline { 2 - 5 } & $\mathrm{r}$ & 0.075 & 0.12 & 0.024 \\
& $\mathrm{p}$ & 0.61 & 0.59 & 0.92 \\
\hline r: Pearson's correlation coefficient test. & &
\end{tabular}

There was a significant increase in SP mean values in the $5^{\text {th }}$ day of postnatal age than the $1^{\text {st }}$ day in control full term, preterm and sick preterm groups, $p$ $=0.046,<0.001$, and $=0.025$ respectively (Table 3 ).

Comparing SP in the control groups to the sick newborn groups showed that there was a significant difference in the sick preterm group than the control preterm on the $1^{\text {st }}$ and $5^{\text {th }}$ day of life; $p=0.003$ and 0 . 037. There was a significant increase between control and sick full term on the $5^{\text {th }}$ day; $P$ value $=0.005$. Furthermore, there was no significant increase in SP between the preterm and full-term infants on the $1^{\text {st }}$ and $5^{\text {th }}$ day of life (Table 4 ).

SP was increased significantly after invasive procedures than non -invasive procedure in the sick full-term and sick preterm infants wether in the $1^{\text {st }}$ or $5^{\text {th }}$ day of life (Table 5).

There was significant correlation between NIPS and SP on the $1^{\text {st }}$ day of life. Furthermore, there was positive, moderate, significant correlation between NIPS and SP after invasive procedures in preterm and full-term groups. It means that there was increase in SP with increase severity of pain score (Table 6).

\section{Discussion}

Pain assessment tools have inadequate indicative significances in the sickest and preterm infants. These scores were endorsed for acute pain, while still no useful tool for chronic or persistent pain. Newborn infants respond and process pain in distinctive way as they have different neurobiology than older infants, children, and adults. The exposure to recurrent agonizing stimuli, strong painful procedures, or repeated mild procedures may permanently modify individual pain processing. The current study looked at the level of SP in normal and sick newborn infants and compared the findings between preterm and fullterm infants as well as studied the relation to type of pain and pain score (NIPS) during the first 5 days of life. Furthermore, the study evaluates the difference between the sick newborn infants and the control groups.
There was a significant increase in SP levels in sick preterm infants in comparison to the control preterm group on the $1^{\text {st }}$ and $5^{\text {th }}$ day of life.

The sick full-term showed non-significant elevation on the $1^{\text {st }}$ day and significant elevation of $\mathrm{SP}$ on the $5^{\text {th }}$ day of life in comparison to the control full-term infants. The increase level of SP among sick groups may be due to the frequent repeated exposure to invasive and noninvasive procedures than the control groups. SP is synthesized in small- and medium-sized neurons of dorsal root ganglia and stored in dense core vesicles and transported by fast axonal transport to both spinal and peripheral nerve terminals [11].

Chronic and persistent pain have an effect on the level of SP. As far as we know there was no reported data compare normal to sick newborn before. There are studies compared SP in infants with sudden infant death syndrome and in normal infants [12], [13], [14].

The study showed significant increase in SP on the $5^{\text {th }}$ day of life whether in control or sick preterm and full-term infants. This is in agreement with a previous study that showed a gradual rise in SP during the first 3 days, which decreased again by day 14 among normal neonates [13].

These data may indicate possibility of exposure of sick infants whether preterm or full term to chronic pain; chronic pain is not simply a temporal continuum of acute pain. In the setting of persistent injury, functional and structural reorganization of neuronal circuits in the CNS leads to long-term changes in perception and behavior [14].

Furthermore, the repeated painful procedures are associated with long-term adverse events as perceptual sensitization blunting of the hypothalamicpituitary-adrenal axis response with subsequent lower thresholds for withdrawal responses that persist for at least the $1^{\text {st }}$ year of life, lower cognitive and motor development at 8 and 18 months, increased sensitivity to childhood injuries, and higher incidence of somatic complaints [16], [17], [18].

There was non-significant increase in the levels of SP among sick preterm infants than fullterm infants. This may be due to more exposure to painful procedures among preterm group. In preterm infants there is imbalance between the plentiful afferent excitatory pain neurotransmitters at birth with the descending inhibitory neurotransmitters that subjected the preterm infants to limited ability to modulate pain [19], it leads to increased nociceptive signaling in the central nervous system in preterm infants. Specific cell populations in the central nervous system of preterm neonates are particularly vulnerable to excitoxicity, oxidative stress, and inflammation [20]. On coronary Wang et al. reported that gestational age has no significant correlation with SP concentrations among normal infants [13]. 
The current study showed a significant increase in the level of SP after invasive procedures in preterm and full-term infants on the $1^{\text {st }}$ and $5^{\text {th }}$ day of life, these results were not reported before as far as we know. This means that aversive and stressful stimuli cause increase in the SP. This finding confirms the rule of SP in acute pain and its association to severity of pain too. SP and its preferred NK-1 receptor has been found within brain areas known to be involved in the regulation of stress and anxiety responses. Stress increases SP efflux in specific limbic structures such as amygdala and septum and that the magnitude of this effect depends on the severity of the stressor. There are changes in SP brain tissue content and subsequent intracerebral SP concentration related to the stressful and aversive stimuli [21].

Tissue damage occurs at birth or shortly after, lead to intense and continuing dendritic sprouting in the local sensory nerve terminals with lowered mechanical threshold and hyperinnervation that persist into adult [19], [22]. Painful stimuli activate more than 1000 genes within the dorsal root ganglion [23]. This trigger unpredicted long-term epigenetic changes when happened during vulnerable period of neuronal plasticity due to early life stress [24].

The study revealed a significant positive correlation between pain score (NIPS) and SP on the $1^{\text {st }}$ day following invasive procedures in sick preterm as $P=0.002$ and in sick full-term $P=0.005$, consequently SP increased with increase severity of pain. It could be as result to modulation effect of SP during early postnatal life on medullary cardiorespiratory and autonomic control [25], [26], whereas, changing breathing pattern is one of the items of NIPS.

It is crucial for neonatologist to diagnose, estimate the grade of pain as early as possible and to minimize the invasive procedures in order to treat neonatal pain effectively. Animal studies have shown that persistent or repeated pain increases apoptosis of neurons, and lead to anxiety-like behaviors during adulthood. In humans, greater exposure to neonatal pain-related stress has been associated with altered brain microstructure and stress hormone levels, that instigate poorer cognitive, motor, and behavioral neurodevelopment in infants and children born very preterm. On the other side, there is evidence that suggests that routine morphine administration in ventilated neonates has no beneficial effects on pain expression and may result in adverse neurological outcomes, and contributes to negative effects on cognitive functioning at 5 years of age [18].

Therefore, it is important that pain-related stress in preterm neonates is accurately identified, appropriately managed, and that pain management strategies are evaluated for protective or adverse effects in the long term [20].

Limitation of the study: There was small number of cases in control groups (10 cases in full term and 10 cases in preterm). We could not include control preterm $<32$ weeks of gestation as they need NICU and were subjected to painful procedures.

\section{Conclusion}

SP might have important role as pain marker in sick preterm and full-term infants, it increases significantly with invasive procedures. Adequate management of pain before the invasive procedure is mandatory. In addition, decrease the frequency of invasive and noninvasive procedures to ensure safe care and improve the quality of life of newborn infants.

\section{Acknowledgments}

Acknowledgement to JESOR- Academy of Scientific Research and Technology (ASRT) for their cooperation and support for patient safety and publishing this article.

\section{Ethical approval}

The approval for this study was obtained from the Ethics Committee of Faculty of Medicine for Girls, AL-Azhar University (approval ID: number 202103751. The registration number is IRB00012239).

The study was run according to the Declaration of Helsinki adopted in 1975 and revised in 2008, and the ethical principles were completely respected.

\section{References}

1. Johnson S, Hollis C, Kochlar P. Psychiatric disorders in extremely preterm children: Longitudinal finding at age 11 years in the EPICure study. J Am Acad Child Adolesc Psychiatry. 2010;49(5):453-63.e1. PMid:20431465

2. Comaru T, Miura E. Postural support improves distress and pain during diaper change in preterm infants. J Perinatol. 2009;29(7):504-7.

PMid:19242484

3. Slater R, Fabrizi L, Worley A, Meek J, Boyd S, Fitzgerald M. Premature infants display increased noxious-evoked neuronal activity in the brain compared to healthy age-matched term-born infants. Neuroimage. 2010;52(2):583-9. https://doi.org10.1016/j. 
neuroimage.2010.04.253

\section{PMid:20438855}

4. Altimier L, Phillips RM. The neonatal integrative developmental care model: Seven neuroprotective core measures for familycentered developmental care. Newborn Infant Nurs Rev. 2013;13:9-22. https://doi.org/10.1053/j.nainr.2012.12.002

5. Lawrence J, Alcock D, Kay J, McGrath PJ. The development of a tool to assess neonatal pain. Journal of Pain and Symptom Management. 1991; 6(3):194 https://doi. org/10.1016/0885-3924(91)91127-U

6. Steinhoff MS, von Mentzer B, Geppetti P, Pothoulakis C, Bunnett NW. Tachykinins and their receptors: Contributions to physiological control and the mechanisms of disease. Physiol Rev. 2014;94(1):265-301. https://doi.org10.1152/ physrev.00031.2013

PMid:24382888

7. Whitfield MF, Grunau RE. Behavior, pain perception, and the extremely low-birth weight survivor. Clin Perinatol. 2000;27(2):363-79. https://doi.org10.1016/ s0095-5108(05)70026-9

PMid:10863655

8. American Academy of Pediatrics, Committee on Psychosocial Aspects of Child and Family Health, American Pain Society, Task Force on Pain in Infants, Children, and Adolescents. The assessment and management of acute pain in infants, children, and adolescents. Pediatrics 2001;108(3):793-7. https://doi. org10.1542/peds.108.3.793

\section{PMid:11533354}

9. ELMeneza S. Egyptian neonatal safety training network: Adream to improve patient safety culture in Egyptian neonatal intensive care units. East Mediterr Health J. 2020;26(10):1303-11. https:// doi.org/10.26719/emhj.20.034

PMid:33103758

10. Lawrence J, Alcock D, McGrath P, Kay J, MacMurray SB, Dulberg C. The development of a tool to assess neonatal pain. Neonatal Netw. 1993;12(6):59-66.

PMid:8413140

11. Hoyer D, Bartfai T. Neuropeptides and neuropeptide receptors: Drug targets, and peptide and non-peptide ligands: A tribute to prof. Dieter Seebach. Chem Biodivers. 2012;9(11):2367-87. https://doi.org10.1002/cbdv.201200288

PMid:23161624

12. Scholle S, Glaser S, Zwacka G, Scheidt B. Plasma levels of beta-endorphin and substance $P$ in the first year of life in full-term and preterm infants. Acta Paediatr Scand. 1990;79(12):1237-9. https://doi.org10.1111/j.1651-2227.1990.tb11416.x PMid:1707578

13. Wong CM, Boyle EM, Stephen RI, Smith JJ, Stenson BJ, Mclntosh $\mathrm{N}$, et al. Normative values of substance $\mathrm{P}$ and neurokinin A in neonates. Ann Clin Biochem. 2010;47(4):331-5. https://doi.org10.1258/acb.2010.010024

PMid:20592332

14. BrightFM, Vink R, Byard RW, Duncan JR, Krous HF, Paterson DS. Abnormalities in substance $P$ neurokinin-1 receptor binding in key brainstem nuclei in sudden infant death syndrome related to prematurity and sex. PLoS One. 2017;12(9):e0184958. https:// doi.org10.1371/journal.pone.0184958

\section{PMid:28931039}

15. Kuner $\mathrm{R}$, Flor $\mathrm{H}$. Structural plasticity and reorganisation in chronic pain. Nat Rev Neurosci. 2016;18(1):20-30. https://doi. org10.1038/nrn.2016.162

PMid:27974843

16. Hermann C, Hohmeister J, Demirakça S, Zohsel K, Flor H. Long-term alteration of pain sensitivity in school-aged children with early pain experiences. Pain. 2006;125(3):278-85. https:// doi.org10.1016/j.pain.2006.08.026

PMid: 17011707

17. Johnston CC, Fernandes AM, Campbell-Yeo M. Pain in neonates is different. Pain. 2011;152 Suppl 3:S65-73. https:// doi.org10.1016/j.pain.2010.10.008

PMid:20971562

18. de Graaf $\mathrm{J}$, van Lingen RA, Simons $\mathrm{SH}$, Anand $\mathrm{KJ}$, Duivenvoorden $\mathrm{HJ}$, Weisglas-Kuperus $\mathrm{N}$, et al. Long-term effects of routine morphine infusion in mechanically ventilated neonates on children's functioning: Five-year follow-up of a randomized controlled trial. Pain. 2011;152(6):1391-7. https:// doi.org10.1016/j.pain.2011.02.017

PMid:21402444

19. Fitzgerald M. Developmental neurobiology of pain. In: Wall PD, Melzack R, editors. Textbook of Pain. Edinburgh, Scotland: Churchill Livingstone; 1999. p. 235-52.

20. Vinall J, Grunau RE. Impact of repeated procedural painrelated stress in infants born very preterm. Pediatr Res. 2014;75(5):584-7. https://doi.org10.1038/pr.2014.16 PMid:24500615

21. Ebner $\mathrm{K}$, Singewald $\mathrm{N}$. The role of substance $\mathrm{P}$ in stress and anxiety responses. Amino Acids. 2006;31(3):251-72. https://doi. org10.1007/s00726-006-0335-9 PMid: 16820980

22. Reynolds ML, Fitzgerald M. Long-term sensory hyperinnervation following neonatal skin wounds. J Comp Neurol. 1995;358(4):487-98. https://doi.org10.1002/cne.903580403 PMid:7593744

23. Hammer P, Banck MS, Amberg R, Wang C, Petznick G, Luo S, et al. mRNA-seq with agnostic splice site discovery for nervous system transcriptomics tested in chronic pain. Genome Res. 2010;20(6):847-60. https://doi.org10.1101/gr.101204.109. PMid:20452967

24. Low LA, Schweinhardt $P$. Early life adversity as a risk factor for fibromyalgia in later life. Pain Res Treat. 2012;2012:140832. https://doi.org10.1155/2012/140832

PMid:22110940

25. Rupniak NM, Carlson EC, Harrison T, Oates B, Seward E, Owen S, et al. Pharmacological blockade or genetic deletion of substance $\mathrm{P}$ (NK1) receptors attenuates neonatal vocalisation in guinea-pigs and mice. Neuropharmacology. 2000;39(8):1413-21. https://doi.org10.1016/s0028-3908(00)00052-6

PMid:10818257

26. BrightFM, Byard RW, VinkR, Paterson DS. Normative distribution of substance $P$ and its tachykinin neurokinin-1 receptor in the medullary serotonergic network of the human infant during postnatal development. Brain Res Bull. 2018;137:319-328. https://doi.org10.1016/j.brainresbull.2018.01.009 PMid:29331576 